Gönderim Tarihi: 21.12.2017 Kabul Tarihi: 23.03.2018

\title{
17. VE 18. YÜZYIL BATILI SEYYAHLARIN ESERLERINDE ÇERKEZ KÜLTÜRÜNE DAİR NOTLAR
}

\author{
Yusuf YILDIZ*
}

\section{NOTES ON THE CIRCASSIAN CULTURE IN THE WORKS OF WESTERN TRAVELERS IN THE 17TH AND 18TH CENTURIES}

\begin{abstract}
$\ddot{O} z$
Kafkasya'da binlerce yıllık bir geçmişe sahip olan Çerkezler, 19. yüzyıldaki Rus işgali ve ardından Ruslar tarafından sürgüne maruz bırakılmadan önce kalabalık bir halk olup Kuzey-Batı Kafkasya'da geniş ve zengin bir coğrafyada yaşamışlar ve kendilerine özgü kültürleri ve yaşam tarzlarıyla dikkat çekmişlerdir. Bugün de hala birçok yönüyle korunan ve yaşatılan Çerkez kültürüne dair 17. ve 18 . yüzyıllarda en yoğun gözlemlerde bulunan ve bu gözlemlerini ve edindikleri diğer bilgileri not edenler özellikle Batılı seyyah ve araştırmacılar olmuştur. İmparatorluğun yeni parçası olarak Kafkasya'yı araştırmak ve tanımak için özellikle Rus Çarlığı tarafından gönderilen bu seyyahların eserlerinde bulunan Çerkezler hakkındaki zengin bilgiler, bugün Çerkez siyasi tarihinin aydınlatılmasının yanında Çerkezlerin kültür tarihine de ş̧ık tutmaktadırlar.
\end{abstract}

Anahtar Kelimeler: Çerkezler, Çerkez Kültürü, Çerkezlerin Toplumsal Yaşamı, Batılı Seyyahlar.

\begin{abstract}
The Circassians, who inhabited the Caucasus for thousands of years, were a large nation before Cherkessia was occupied by the Russians in the 19th century and its people were forced into exile. They lived in the Northwest Caucasus, which was a large and fertile area, and aroused interest because of their distinctive culture and lifestyle. In particular, the Western travelers and researchers observed the Circassian culture, which is still preserved and kept alive in many respects, very intensively in the 17th and 18th centuries and recorded their observations and other information they found about the Circassians. The detailed information about the Circassians, that can be found in the works of these travelers, who were sent to the Caucasus by the Russian Empire to explore this region as a new part of the empire,
\end{abstract}

* Dr. Öğr. Üyesi, Abant İzzet Baysal Üniversitesi, Fen Edebiyat Fakültesi, Tarih Bölümü, e-posta: yusufyildiz@ibu.edu.tr. 
illuminate not only the political history of the Circassians but also their cultural history.

Keywords: Circassians, Circassian Culture, The Social Life of the Circassians, the Western Travelers.

\section{Giriş}

Kendilerini “Adıge” olarak adlandıran Çerkezler, Kafkasya'nın en eski ve köklü halklarından olup Kuzey-Batı Kafkas dil ailesine mensup bir dil konuşurlar. Çerkezler, Rus işgalinden önce, Kafkas Dağları'nın iki yanı, Karadeniz' in doğu kıyıları, Orta Kuban, Taman Yarımadası ile birlikte Aşağı Kuban, Terek Nehri'nin batı kıyıları ve Kabardey Platosu'nu içine alan geniş bir bölgede ${ }^{1}$ yaşıyorlar ve birçok kabileden oluşuyorlard1. Zengin doğal kaynaklara sahip olan Çerkezistan, tarihte sadece Bizans İmparatorluğu, Kırım Hanlığı, Osmanlı İmparatorluğu, Rus Çarlığı gibi güçlerin değil, aynı zamanda Venedik ve Ceneviz gibi ticarette öne çıkan devletlerin de ilgisini çekmiş ve bu güçlerden her beri belli bir dönem bölgede egemenlik kurmuştur. Ruslar tarafından, 19. yüzyılın ikinci yarısında kendi öz vatanlarından kovulmadan önce Kafkasya'nın en kalabalık halklarından biri olan Çerkezlerin büyük bölümü bugün, başta Türkiye olmak üzere çeşitli ülkelerde yaşamaktadır. ${ }^{2}$ Kafkasya'da kalan Çerkezler ise, Rus parçala yönet siyasetinin bir sonucu olarak, Rusya Federasyonu'na bağlı Adıge, Karaçay-Çerkezya ve Kabardino-Balkarya isimli üç farklı özerk cumhuriyete dağıtılmışlardır. Fakat Çerkezler, buna rağmen kimliklerini ve kendilerine özgü kültürlerini büyük ölçüde korumayı başarmışlardır (Natho 2009: 17; Berkok 1958: 174-184; Sarkisyanz 1961: 99).

\footnotetext{
${ }^{1}$ Kuzey Kafkasya'nın batı kesimlerini içine alan ve eskiden Çerkezlerin yoğun olarak yaşadığı Kuban bölgesi ismini Kuban Nehri'nden almıştır. Karşısında yer alan Kırım gibi Azak Denizi'ni Karadeniz'den ayıran Taman Yarımadası da yine tarihi Çerkez bölgelerinden biri olup bugün Rusya'nın Krasnodar bölgesi içinde yer alır. 623 km uzunluğundaki Terek Nehri, Gürcistan'daki Büyük Kafkaslarda bulunan Silgiçoh buzulundan doğmakta ve Kuzey Kafkasya'dan geçerek Hazar Denizi'ne dökülmektedir. Kabardey Platosu da Terek Nehri'nin doğduğu bu bölgeye yakın bir mesafede bulunur (Reineggs 1796: 3 vd).

${ }^{2}$ Çerkezlerin yoğun olarak yaşadığı diğer ülkeler, Suriye, Ürdün, İsrail, Almanya ve Hollanda başta olmak üzere Avrupa ülkeleri ve Amerika'dır (Hoppe 2011, https://www.eurasischesmagazin.de/artikel/Die-Tscherkessen-einunbekanntesVolkerwacht/20111009, 3 Nisan 2018'de erişildi).
} 
Binyıllara yayılan uzun bir süreçte şekillenen Çerkez kültürü ve yaşam tarzı, 17. yüzyıldan itibaren Batılı seyyahların da yoğun ilgisini çekmiştir. 17. yüzyılda Çerkezler hakkında ayrıntılı bilgiler sunan seyyahların başında Fransız Jean-Baptiste Tavernier gelir. 18. yüzyılın ikinci yarısına gelindiğinde, özellikle Kafkasya'yı işgale başlayan Rus Çarlığı'nın bölgenin zenginliklerini araştırmak istemesiyle Kafkasya’yı ziyaret eden seyyahların sayısı da artmaya başlamıştır. Bu seyyahların çoğunun, 1724 y1lında kurulan Rus Bilimler Akademisi'nde ${ }^{3}$ görev yapan Alman kökenli doğa araştırmacıları oluşu dikkat çekicidir. Bunda, dönemin hükümdarı Çariçe II. Katharina'nın da (1762-1796) Alman kökenli oluşunun bir rolü olduğu açıktır. Konumuz için eserlerine başvurduğumuz bu seyyah ve araştırmacılar, Johann Anton Güldenstädt ${ }^{4}$, Jokob Reineggs ${ }^{5}$, Peter Simon Pallas $^{6}$ ve Johann Gottlieb Georgi'dir ${ }^{7}$. Bu çalışmanın amacı, aynı zamanda doğa araştırmacısı da olan bu seyyahların eserlerini esas alarak Çerkezlerin 17. ve 18. yüzyıldaki kültürü ve sosyal yaşamı konusunda öne

\footnotetext{
${ }^{3}$ Rus Bilimler Akademisi, 8 Şubat 1724 tarihinde, doğa bilimleri ve soysal ve beşeri bilimler alanlarında geniş çaplı araştırmalar yapmak için Çar Büyük Petro (1682-1721) tarafindan Sankt Petersburg'ta kurulmuştur (Komkov, Levşin ve Semenov 1981: 39).

4 Johann Anton Güldenstädt (1745-1781), Berlin'de botanik ve doğa tarihi okumuştur. Tıp eğitimini tamamlayıp 1767 yılında doktor olmuştur. Bir yıl sonra II. Katharina adına Rusya'nın güney sınırlarını araştırmak için Rus Bilimler Akademisi tarafindan Kafkasya'ya gönderilen Güldenstädt, Kuzey Kafkasya'dan Gürcistan'a kadar gelmiştir (Fauser 1966: 254-255).

${ }^{5}$ Bir Alman diplomat, doktor ve doğa araştırmacısı olan Jokob Reineggs (17451781), Osmanlı Devleti'ne bir seyahat düzenlemiş, buradan Gürcistan'a geçmiş ve Kral II. Erekle'nin güvenini kazanarak kralın saray doktoru olmuştur. 1782 y1lında St. Petersburg'a yerleştikten sonra Prens Potyomkin'in güvenini kazanan Reineggs, Rusya'nın Kafkasya'daki bazı diplomatik görevlerine katılmış ve böylece Kafkasya'yı bizzat tanıma imkânı bulmuştur (Schipperges 1966: 586597).

${ }^{6}$ Alman coğrafyacı, doğa araştırmacısı ve seyyah Peter Simon Pallas (1741-1811), Halle ve Göttingen üniversitelerinde okumuştur. Dil alanında oldukça yetenekli olan Pallas, Latince, Yunanca, İngilizce ve Fransızca'nın yanında, daha sonra Rusya'da Rusça ve Tatarca da öğrenmiştir. 1767 yılında Rus Bilimler Akademisi'ne üye olmuş ve 1768-1794 yılları arasında Sibirya ve Kafkasya'ya iki araştırma seyahati düzenlemiştir (Gärtner 2001: 14-16) .

7 Johann Gottlieb Georgi (1729-1802), Alman coğrafyacı, kimyacı ve bitki bilimcidir. 1769 yılında St. Petersburg'a yerleşmiştir. 1770 yılından itibaren Rusya'nın çeşitli bölgelerine düzenlenen seyahatlere katılmıştır. 1775 yılında Rus Bilimler Akademisi'nde çalışmaya başlamıştır (Wendland 1992: 119).
} 
çıkan noktaları tespit edip Çerkez kültürünün tarihsel gelişim sürecinin daha iyi anlaşılmasına katkı sağlamaktır.

\section{Jean-Baptiste Tavernier}

Çerkezlerin, dinleri, örf ve adetleri, alışkanlıkları, yani kısaca Çerkezlerin sosyo-kültürel yaşamına dair başvurmamız gereken en eski Batılı kaynaklardan biri, şüphesiz Fransız seyyah Jean-Baptiste Tavernier'in (Ölm. 1689) seyahatnamesidir. Tavernier, 1628-1668 yılları arasında doğuya, yani Türkiye, İran ve Hindistan'a altı seyahat düzenlemiştir. Bu seyahatleri esnasında Kafkasya'yı da tanıma imkanı bulan seyyah, Çerkezler hakkında değerli ve ayrıntılı bilgiler sunmaktadır.

Tavernier, Çerkez kültürü ve sosyal yaşamı hakkında bilgi vermeden önce, kısaca Çerkezlerin yaşadığı coğrafyayı tasvir etmektedir. Seyyahın tasvirine göre Çerkezlerin yaşadığı bölge, birçok dağ, tepe, orman, su kaynakları ve çayların bulunduğu oldukça zengin bir doğaya sahip bir memleketti. Doğada çeşit çeşit çiçekler, özellikle de güzel laleler bulunmaktayd1. Ayrıca burada yetişen, en küçügü findık büyüklüğünde olan, sarıya yakın soluk renkli bir çilek türü Tavernier'in çok dikkatini çekmişti. Toprak o kadar verimliydi ki, insanlar, neredeyse hiç zahmete girmeden her türlü meyveyi bolca bulabiliyorlardı. Tarımla kısmen meşgul olan Çerkezler, ne ekin ne de yulaf ekiyorlard1. Arpa sadece atlar için yetiştiriliyordu. Buna karşın bol miktarda darı ekiliyordu. Darıdan yapılan ekmek, Çerkezlerin çok sevdiği bir besindi. Çerkezlerin en büyük zenginliği ise sığır ve İspanyol atlarına benzeyen iyi cins ve kaliteli atlardı. Ayrıca bol miktarda koyun ve keçi besleniyor ve bunların yünlerinden de yararlanılıyordu. Buna karşın inek ve öküz gibi büyük baş hayvanlara Çerkezistan' da fazla rastlanmaması, bu hayvanların, ülkeyi zenginleştiren hayvanlardan sayılmıyor oluşundand1.

Tavernier'e göre Çerkezler, köklü bir av kültürüne sahip olan bir halktı. Çerkezistan'da bol miktarda bulunduğu için genellikle yabani geyik avlanıyordu. Çerkezler ava giderken ne köpekleri ne de kuşları kullanmışlardır. Çünkü ava, genellikle bir köyden yedi ya da sekiz seçkin avcı bir grup oluşturarak çıkmıştır. Çok iyi atlara sahip olan bu avcılar, yabani hayvanları kovalayıp yormak suretiyle onları halatla boyunlarından yakalayacak kadar ustalaşmışlardır. Avcılar, bir geyiği öldürür öldürmez hemen ayaklarını kesmişler ve kemikleri ezerek içindeki iliği çıkarmışlardır. Çünkü onların düşüncesine göre vücudu, bu ilikten daha güçlü ve dirençli yapacak daha kuvvetli bir besin kaynağı yoktu. 
Tavernier'in notlarından anladığımız kadarıyla, Çerkez kültürünün en belirgin unsurlarından biri de Çerkezlerin kendilerine özgü giyim kuşamlarıdır. Çerkez kıyafetlerin en dikkat çekici özelliklerinden biri, yapımlarında rahatlığın esas alınmasıdır. Tavernier'e göre kadın ve erkek elbisesi arasında hemen hemen hiç fark yoktu. Görünüş olarak, kadınların kıyafeti erkeklerin kıyafetine, k1z çocuklarının kıyafeti ise oğlan çocuklarının kıyafetine benzemekteydi. Çocuklar, pamuktan yapılmış renkli bir etek ve tuvalet ihtiyaçları olduğunda çözmeden kaldırabilecekleri şekilde tasarlanmış olan geniş bir pantolon giyerlerdi. Ayrıca üzerlerinde, tam olarak dizlerine kadar ulaşmayan işlemeli küçük bir gömlekleri olurdu. Onun üzerine de kaba bezden yapılmış dizlere kadar uzanan ve ortasına bir ip kemer taktıkları kollu bir etek giyerlerdi. Bu eteklerin üstten ve alttan kesilmiş olan kollarını arkadan sırtlarına bağlarlardı. Erkekler, 60 yaşına yaklaşmadan sakal bırakmazdı. Erkek, kadın, oğlan, kız herkesin saçı kulaklardan aşağı inmezdi. Hem gençler hem de yaşlılar, kafalarının tam ortasını, alından başlayarak enseye kadar iki parmak kalınlığında tıraş ettirirdi. Kadın ve erkekler, etekleriyle aynı kumaştan yapılmış küçük bir başlık takardı. Fakat evlendikten sonra başlarını biraz değiştirirler ve kafalarının arkasına, beyaz bir örtü ile örttükleri keçeden bir top takarlardı. Ayrıca alt kısmı ayak bilekleri üzerinde kalan üst kısmı ise dizlere bağlanan uzun bir çorap giyerlerdi. Üstünde sadece bir dikiş yeri olan ayakkabıları çok hafifti. Çerkezler, elbiseleri gibi yataklarının da rahat oluşuna özen göstermişlerdir: Yataklar, birkaç koyun postu birbirine dikilip darı yaprağı ile doldurularak yapılmaktaydı. Harmanladıktan sonra yulaf samanı kadar küçülen darı yaprakları, yataktan kalkıldığında kendiliğinden tekrar şişerek yatağı konforlu kılıyordu.

Evlenmek ve aile kurmak, Çerkez toplumunda da vazgeçilmez bir gelenekti. Eğer bir genç, evlenmek istiyorsa ve hoşuna giden genç bir kız bulduysa, yakın akrabalarından birini, kız tarafına ne verileceğinin kararlaştırılması için kızın ailesine göndermiştir. Eğer kızın anne babası yoksa, o zaman bu görevi bir yakını ya da velisi yerine geçen bir temsilci üstlenmiştir. Kız ve erkek tarafının birbirine verdiği şeyler, genellikle at, inek ya da diğer sığırlardan oluşmaktaydı. Gelin ve damat aynı köydense ve düğün pazarlığı yapıldıysa, damadın akrabaları, köyün lideriyle ve damatla birlikte gelinin evine gider ve düğün hazırlıkları yapılırdı. Dügünde yapılan destansı bir dans gösterisinden sonra, damat gelini alıp yatmaya giderdi (Tavernier burada gerdeği kastediyor). Ama eğer gelin ve damat farklı köylerdense, önce gelini almaya başka köye gidilirdi. Yı1lar 
geçmesine rağmen çiftin çocukları olmazsa, erkeğin, çocuğu olana kadar birçok kadınla evlenmesine izin verilirdi.

Eğer evli çiftler, birbiriyle anlaşamayıp artık birbirine tahammül edemez hale gelirse, erkek köyün liderine gider ve karısı hakkında şikayette bulunurdu. Bu durumda köle ticaretiyle de uğraştığı anlaşılan lider, kadını yanına getirtir, onu satar ve adama başka bir kadın verirdi. Eğer önce kadın şikayette bulunursa, aynı şey erkeğin başına gelirdi. Bu, huzuru sağlamaya yönelik bir tedbir olarak görülmüştür. Çünkü Çerkezler, kendi aralarında sükunet içinde yaşamak için her türlü çareye başvurmuşlardır. Örneğin, bir karı kocanın komşularıyla sık sık anlaşmazlık içinde olduğu durumlarda, komşuları onları köyün liderine şikayet ederse, karı koca yakalatılıp yabancı köle tüccarlarına satılabiliyordu.

Efsaneleşen Çerkez güzelliğini "Bu halkların güzel bir nesli var" diyerek Tavernier de dile getirmektedir. Tavernier'e göre çok güzel ve düzgün fizikli olan Çerkez kadınları, 45-50 yaşına gelene kadar daima genç gözüküyordu. Demiri topraktan kendileri çıkaracak ve işleyecek kadar çalışkan olan kadınlar, demirden her türlü araç gereci yapabilmekteydiler. Ayrıca onlar, altın ve gümüşten bütün sanatsal el işlerinin üretiminde de çok ustaydılar. Bu el işleri, ya atların eğeri üzerine örtülmüş ya da ok, yay, ok sadağı, bağ ve mendil gibi ürünlerin süslenmesinde kullanılmıştır.

Soyluların yaşamına gelince, Tavernier'e göre, onlar, bütün gün hiçbir şey yapmaz, evde oturur ve az konuşurlardı. Akşam olduğu zaman bazen ata binip evden çıkarlardı. Bir yere ganimet amaçlı saldırı düzenlemek istedikleri zaman, 30-40 kişi bir araya gelip bir toplanma yerinde buluşan soylular, hem kendi ülkelerinde hem de komşu memleketlerde çapulculuk yapar ve çıktıkları seferlerden çok sayıda köleyle dönerlerdi. Soylu kadınlar ve kızlar ise zamanlarını dikiş nakış işleri ve iğneyle yapılan diğer uğraşlarla geçirirler ve çok zarif ürünler ortaya çıarırlardı.

Tavernier'in, özellikle Çerkezlerin törenleri ve bayramları hakkında ayrıntılı bilgi verişi, onun bu konuya özel bir ilgi duyduğunu göstermektedir. Seyyah, Çerkezlerin soysal hayatının çok önemli bir parçası olduğu anlaşılan tören ve bayramlarından bahsetmeden önce, " $B u$ halklar, ne gerçek Hristiyan ne de Müslümandır, onların dininin tamamı, zaman zaman mümkün olduğunca gösterişli yaptıkları birkaç ayinden ibarettir." diyerek bu tören ve bayramların ilahi dinlerden çok halkın eski inanç ve alışkanlıklarıyla kaynaşıp iç içe geçtiğini ortaya koymaktadır. 
Seyyahın verdiği bilgilere göre Çerkez tören ve bayramlarını şöyle özetleyebiliriz:

Çerkezlerin en önemli toplumsal etkinliği, içinde kısmen dini unsurlar da taşıdığını gördüğümüz güz sonunda düzenledikleri bir bayramdı. Çok sevilen bu bayramın en önemli özelliği, köydeki en yaşlı üç adamın idaresinde geleneksel bir ziyafetle kutlanmasıydı. Ziyafetin tamamını bu yaşlılar yönetirdi. Bu adamlar, bir koyun ya da bir keçi alır ve bazı dualardan sonra hayvanı keserdi. Koyun, temizlendikten sonra, akciğerleri hariç bir bütün olarak pişirilirdi. Akciğer ise ayrı bir yerde kızartılırdı. Piştikten sonra bir masanın üzerine konan et, köy halkının tamamının toplanabileceği çok büyük bir samanlığa taşınırdı. Daha sonra bu üç yaşlı adam, masa önünde ayakta durur, erkek, kadın, çocuk, halkın tamamı da onların arkasında yerlerini alırdı. Yaşlılar, masanın üstündeki hayvanın dört ayağını ve kızartılan akciğerlerini büyük bir bardağa konan boza ile birlikte halkın göreceği şekilde başlarından yukarı doğru kaldırırdı. Köylüler de yemek ve bozayı görür görmez kendilerini hemen yere atar ve yaşlılar ellerindekini tekrar masaya koyana ve bazı konuşmalar yapana kadar kalkmazlard1. Konuşma bitince tekrar ayağa kalkılırdı. Bu arada yanlardaki iki yaşlı, ortadaki yaşlıya birer parça et ve bir bardakla içecek sunar, daha sonra da kendileri birer parça et alırd1. Üçü de etten yedikten sonra, bardaktan ilk önce ortadaki yaşlı içer, daha sonra bardağ1 bırakmadan sırasıyla sağındaki ve solundaki yaşlilara içirirdi.

Törenin bu ilk kısmı icra edildikten sonra, yaşlılar halka döner ve onlara da et ve içecek sunardı. Elbette ilk önce halkın liderine ya da hükümdarına daha sonra halka ikramda bulunulurdu ve etten büyük küçük herkes yerdi. Koyunların kesilen dört ayağına gelince, onları da tamamen bitene kadar yemek adetti. Daha sonra yaşlılar, üzerinde koyunun bulunduğu masaya otururlardı. En yaşı1 adam, koyunun kafasını alır, biraz yer ve yemeleri için sırasıyla diğer ikisine uzatırdı. Daha sonra en yaşlı olan adam, koyunun kafasını üçüncü yaşlıya vererek köyün liderine götürmesini emrederdi. Koyunun kafasını büyük bir saygıyla kabul eden lider, biraz yedikten sonra, yakın akrabalarına ya da en iyi arkadaşlarına verirdi. Böylece koyunun kafası, tamamen yenene kadar elden ele dolaşırdı. Bunun ardından üç yaşlıdan her biri, koyunun vücudundan bir iki parça yemeye başlar ve sonra köyün liderini yanına çağırırdı. O da büyük bir saygıyla korkudan titreyerek yaklaşır, kendisine bıçak uzatan yaşlının elinden bıçağı alır ve koyundan bir parça et kesip yedikten ve bozayı içtikten sonra büyük bir saygıyla geri çekilirdi. Aynı işlemi, bütün köy halkı da 
tekrarlardı. Koyunun kalan bacakları ise çocuklara verilir, hatta onlar bunun için kavga ederdi. Görüldüğü gibi ziyafetin vazgeçilmez unsurlarından biri de boza idi. Tavernier'in verdiği bilgiye göre, Çerkezistan'da ne şarap, ne tütün ne de kahve içiliyordu. Çerkezlerin baş içeceği, su ve şarap gibi sarhoş edici bir özelliği olan bozaydı ve onlar bunu çok seviyordu.

Çerkezlerin, çayırlar biçilmeden önce kutladıkları başka bir bayramları daha vardı. Bu nedenle bu bayrama çayır bayramı ya da şenliği demek doğru olacaktır. Geleneğe göre, maddi durumu iyi olan her vatandaş, bu bayramda bir keçi satın alırdı (törenlerde keçi koyundan daha değerli görülüyordu). Bazı kişiler de maddi durumuna göre, ya bir koyun ya da bir kuzu tedarik ederdi. Bu hayvanlar, bir araya toplandiktan sonra, herkes kendi hayvanını kesip derisini yüzerdi. Fakat, hayvanın ayakları ve kafası derisinden ayrılmazdı. Sonra hayvanın iki ön ayağı ve iki arka ayağı arasına birer sopa geçirerek deri gerilir ve toprağa çakılan ve en üst ucuna hayvanın kafasının geçirili olduğu bir ağaca asılırdı. Herkes hayvanına aynı işlemi uygular ve derisini köy meydanına asardı. Hayvanların pişirilen etleri ise, köy meydanında kurulan büyük bir sofraya konurdu. Bazen birkaç köyün birleşerek ziyafet düzenlediği de görülürdü. Yaşl1lar, yine bu ziyafette de önemli bir rol oynard1.

İlk olarak yaşlılar ve köyün lideri etten yedikten sonra, geri kalan etler, halka ikram edilirdi. Bazı köylerde, keçi, koyun ve kuzu olmak üzere 50 kadar hayvan kesilir ve genellikle 200 litre kadar da boza tüketilirdi. Halk, bütün gününü bu ziyafette yiyip içerek, hoplayıp zıplayarak ve flüt eşliğinde dans ederek geçirirdi. Çerkezler, flütle yapılan müzikten başka bir müziğe sahip olmadıkları için, yan yana duran birçok flütçünün aynı anda çaldığı flüt eşliğinde dans ederlerdi. Flütçülerden birincinin flütü kol uzunluğunda, diğerlerininki ondan biraz küçük, sonuncunun flütü ise en küçük olandı. Yaşlılar, sofradaki paylarını aldıktan sonra ziyafetten ayrılır, genç oğlanları ve kadınları danslarıyla baş başa bırakırdı. Kalanlar ise içecekleri yettiği kadar eğlenirlerdi. Halkın sabahki ilk işi çayırları biçmek olurdu.

Çerkezlerde "yıldırım dansı" diye adlandırabileceğimiz dini yönü ağır basan bir âdet daha vardı. Bu âdete göre gök gürlediği zaman bir köyden herkes köy dışına gider, genç oğlanlar ve kızlar, oturan yaşlıların huzurunda dans edip hoplayıp zıplamaya başlardı. Eğer aralarından birine yıldırım çarparsa, bu kişi gösterişli bir şekilde defnedilir ve onun, Tanrı'nın rahmetine nail olan bir aziz olduğuna inanılırdı. Ama eğer y1ldırım 
aralarından birinin evine isabet ederse ve ne erkek ne kadın, ne çocuk ne de bir hayvan yaralanmazsa, bu durumda o hanede yaşayanlara, bir yıl boyunca dans edip hoplayıp zıplamaktan başka bir iş yapmama hakkı verilirdi. Daha sonra dört bir yana gönderilen adamlar, en güçlüsünden beyaz bir koç bulurlardı. Bu koç, yıldırım isabet eden evin bulunduğu köyün halkı tarafından beslenir ve başka bir yere yıldırım isabet edene kadar ona büyük saygı gösterilirdi. Y1ldırım isabet eden ev halk1 ise, bütün akrabaları ve arkadaşlarıyla birlikte köyden köye dolaşırdı. Köylere girmeyip köy dışında bir yerde dans edip hoplayıp zıplayan bu insanlara herkes birer hediye getirirdi. Aynı ev halkı, koçun boynuna bir parça peynir asarak, onu belirlenen bir günde ilkbaharda da ülkenin en seçkin köyüne götürürdü. Ancak, köye yine girilmez, köy halkı, köy dışına onların yanına gelirdi. Koça saygıdan kendilerini yerlere atan köylüler, koçun sahiplerine yemek ve bol bol sadaka verirdi. Onlar, bu şekilde bütün ülkeyi köy köy gezip büyük miktarda bağış toplardı.

Tavernier'in en çok ilgisini çeken Çerkez adetlerden biri de, Çerkezlerin çeşitli hasta tedavi yöntemleri olmuştur. Esasında batıl inançlara dayanan bu yöntemlerin hastaları iyileştirmekten çok bir kazanç yolu olarak görüldüğü anlaş1lmaktadır. Tavernier, bu yöntemlerden en ilginç olarak gördüğü üç tanesinden bahsetmektedir. Buna göre Çerkezlerde Avrupa'daki büyük ciltli kitapların ebatında tek kitap vardı. Yaşıı bir adamın eli altında bulunan bu kitaba, sadece o dokunabiliyordu. Bu yaşlı adam öldüğünde, kitabın koruyucusu olarak başka bir adam seçiliyordu. $\mathrm{Bu}$ adamın işi, o kitapla birlikte hastaların bulunduğu köylere gitmekti. Adam, ziyaret ettiği hastanın yanında bir mum yakar ve hastayla odada yalnız kalırdı. Kitabı, hastanın göğsüne koyduktan sonra açıp okur ve son olarak, nefesi hastanın yüzünün altına gelecek şekilde hastaya birkaç kez üflerdi. Daha sonra kitabı hastaya defalarca öptürür ve onun başına koyard1. Bu işlem, yaklaşık olarak yarım saat sürmekteydi. Yaşlı adam, işini bitirip giderken ona ödül olarak ya bir keçi, ya bir koyun, ya bir öküz ya da bir inek verilirdi. Adam bu şekilde, bir servet kazanıyordu.

Çerkezlerde hastalıkları iyileştiren kadınlar da bulunuyordu. Yine aynı şekilde para karşılığ 1 faaliyet gösteren bu kadınlar, çok daha ilginç bir tedavi yöntemi uyguladıkları için Tavernier onları "geğiren kadınlar" olarak adlandırmaktadır. Seyyahın anlattığına göre bu kadınlar ilk olarak, hastanın vücuduna, özellikle de vücudun ağrıyan kısmına dokunuyorlardı. $\mathrm{Bu}$ işlemi birçok kez tekrarladıktan sonra hastanın ağzına geğiriyorlardı. Hastanın ağrısı ne kadar çoksa kadınlar da o kadar güçlü geğirmek 
zorundayd1. Bu geğirmeyi dinleyen etrafındaki kişiler, bunun hasta için çok şifalı olduğuna ve hastanın ağrısını hafiflettiğine inanıyordu. Tedavinin sonucu ne olursa olsun bu kadınlara para ödenmekteydi. Yine başka ilginç bir âdet de başı ağrıyan insanların, tedavi olmak için sadece berbere gitmesidir. Hastanın bacağını, bıçakla iki yerden kesen berber, daha sonra oraya yaranın tekrar iyileşmesi için bir merhem sürüyordu. Çünkü insanlar baş ağrısının, deri ile bacak arasında bulunan bir yelden kaynaklandığını ve eğer keserek havayı alırlarsa ağrıdan kurtulacaklarını düşünüyordu.

Çerkezlerin ölü defnetme ve ölümlere verdiği tepki konusunda da bazı kısa bilgiler veren Tavernier, onların, ölülerini mezara götürürken, ölenin arkadaşları ile anne babasının korkunç bir şekilde feryat ettiğini yazmaktadır. Hatta üzüntüsünü aşırı göstermek isteyen bazı kişiler, yüzünün ve vücudunun değişik yerlerini kesici çakıl taşlarıyla tırmalıyor, bazıları da kendini yere atıyor ve saçlarını yoluyordu. $\mathrm{Bu}$ nedenle, defnetme işlemi bittikten sonra eve dönenler, âdeta kana susamış bir hal sergiliyorlard1. İlginç ki, ölülerini defnederken kendilerine bu şekilde işkence eden bu insanlar, ölüleri için hiç dua etmiyorlardı (Tavernier 1681: 144-147).

Resim 1: Çerkez Köyleriyle Aynı Mimari Yapıda Olan Bir Kumuk Köyü

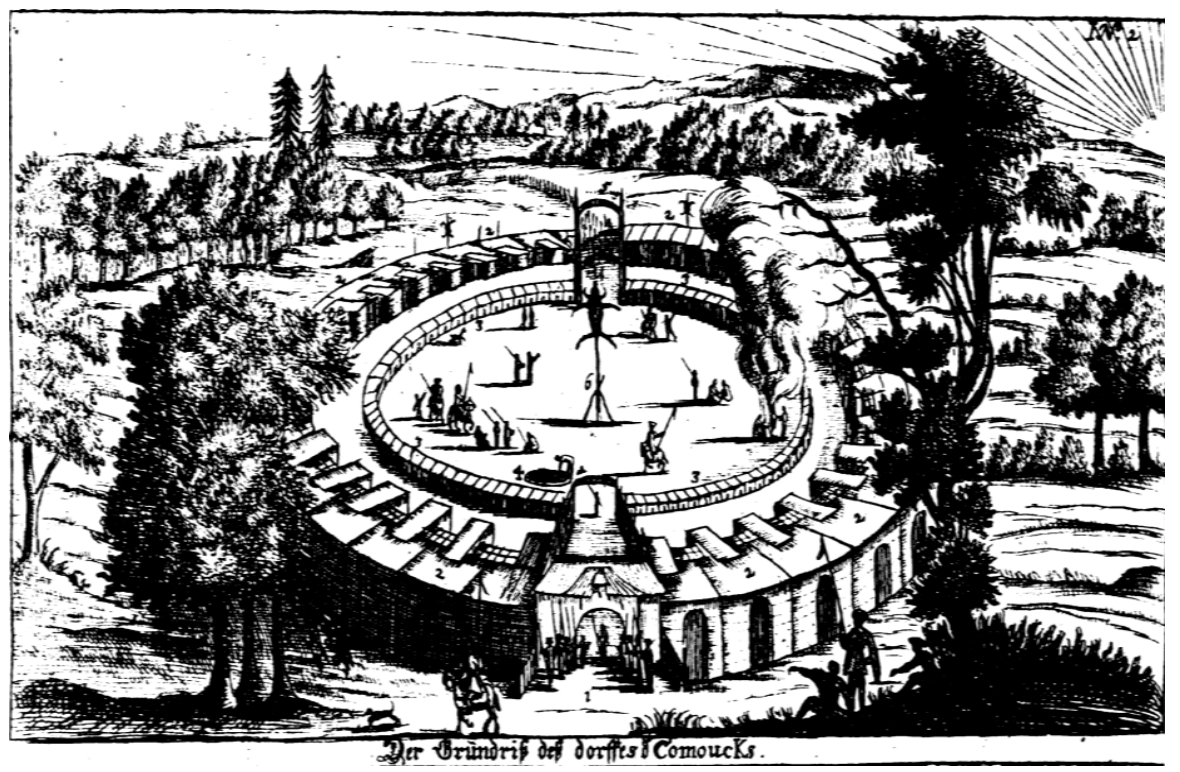

Kaynak: Tavernier 1681: 144 


\section{Johann Anton Güldenstädt}

1764 yılında Rus Bilimler Akademisi ${ }^{8}$ tarafindan II. Katharina ${ }^{9}$ adına Rus İmparatorluğu'nun sınırlarını araştırmak için gönderilen ve Çerkezistan'da da bulunan Doğa Araştırmacısı Johann Anton Güldenstädt (Ölm. 1781), Çerkezler ve onlarla akraba bir halk olan Abazalar hakkında bazı ilginç gözlemlerde bulunmuştur. İlk önce Abazalardan bahseden Güldenstädt, bu halkın Çerkezlere en çok benzeyen halk olduğunun, bu nedenle de onlarla hemen hemen aynı yaşam tarzını paylaştıklarının altını özellikle çizmektedir. Güldenstädt'e göre Çerkezler, dil ve toplumsal hususiyetleri bakımından Abazalar dışında hiçbir halkla akraba olmayan özel bir halktı. Abazaca ve Çerkezce "aynı anadan doğmuştu", ancak bu iki halk, çok farklı lehçeler konuştukları için pratik yapmadan birbirlerinin dilini anlayamamıştır. Abazalar, etekleri biraz daha kısa olsa da Çerkezler gibi giyinmişlerdir. Kılıç, ok, yay ve av tüfeği gibi silahlar kullanmışlardır. Onlar da Çerkezler gibi duvarları örülmüş çalıdan oluşan hafif yarım kargir evler yapmışlardır.

Çerkezler, kendilerini "Adıge" olarak adlandırmışlardır. Türkler ve Tatarlar ise onlara "Çerkas" demiştir. Çerkezistan'da, halkın bağlı olduğu birçok prens ve güçlü bir asiller sınıfı bulunuyordu. En önemli soylu aileler, Cambulat, Kaytuk, Bekmursa, Moisol ve Kargokin aileleriydi. Çerkezlerin ortak bir hükümdarı olmamıştır. Ülkenin ortak bir anayasası olmasına rağmen, bölgeler arasında düzenli bir bağ ve ilişki de bulunmuyordu. Prensler arasında birlik olmadığı gibi, onlar arasında düşmanlık ve savaş hakimdi. Böylece Rus hakimiyetini tanımak zorunda kalan Çerkezler, bu bağlılığın garantisi olarak seçkin ailelerden Kızlar Kalesi'nde tutulmak üzere Ruslara rehineler vermişlerdir.

İlginçtir ki, Güldenstädt, Çerkezlerlerin dini inanışları hakkında sadece genel bilgiler veriyor ve onların ne Hristiyanlık ve İslam öncesi döneme ne

\footnotetext{
${ }^{8}$ Yukarı bkz. dipnot 2.

9 Aslen Alman asıllı olan II. Katharina, 1729 y1lında Anhalt-Zerbst prensesi Sophie Auguste Friederike olarak dünyaya gelmiştir. 1745 yılında 14 yaşındayken, daha sonra III. Petro olarak kısa süre tahta oturacak olan Petro Fyodoroviç ile evlendirilmiştir. Kısa sürede Rusça'yı öğrenen ve Rus kültürüne entegre olan Katharina, Protestanlık'tan Ortodoksluğa geçmiştir. 1762 yılında teyzesi I. Katharina ölümü üzerine III. Petro olarak Rus tahtına oturan Petro Fyodoroviç, muhafız alayı tarafından tahttan indirilmiş ve yerine karısı II. Katharina olarak tahta oturtulmuştur. II. Katharina, 1796 y1lında ölene kadar ülkeyi 34 yıl yönetmiştirm (Aretz 2012: 7-85).
} 
de bu dinlere ait âdetlerinden ya da bayramlarından bahsediyor. Onun tespitine göre, vaktiyle Gürcü ve Rus din adamlarının, özellikle Çar İvan Vasilyeviç'in ${ }^{10}$ gayretleriyle Çerkezler arasında Ortodoksluk yayılmıştır. Kuma ve diğer bölgelerdeki eski taş kiliseler, mezarlarda bulunan haçlar ve bu dine ait diğer birçok iz de bunu kanıtlamaktadır. Ama artık birçok Çerkez soylusu Müslüman olmuştur. Buna rağmen, onların ne din adamları ne camileri ne de dini okulları vardı ve İslam'ı çok az tanımaktaydılar.

Güldenstädt'in tespitine göre Çerkezler, görünüş ve karakter olarak Abhazlara benzeseler de onlardan hissedilir şekilde daha kararlı ve zarif, ancak aynı zamanda müzakerelerde çok daha güvenilmezdiler. Sıkça rastlanan bazı Çerkez erkek isimleri şunlardı: Ali, Muhammet, Moisol (Musa), Arslanbek, Temu, Çammursa, Tamassa, Catemir. Çok rastlanan kadın isimleri ise Kenşa, Fatme, Tepsike, Kistamar ve Cenet'ti. Çerkezler genellikle hayvancılıkla, özellikle koyun besiciliğiyle uğraşmışlardır. Koyunları, Avrupa'daki sıradan koyunlara benzese de, yünleri çok kaliteliydi. Sayıları çok olmamakla birlikte, Çerkezlerin iyi cins atları da vardı. Yünü, hem işleyerek kaba kumaşlar ve keçe yapmışlar hem de satmışlardır. Kalın darı, Çerkezlerde ekmek yerine geçtiği için tarımları, hemen hemen sadece darı ekimiyle sınırlı kalmıştır. Çerkezlerin şehirleri yoktu, onlar büyük köylerde yaşamışlardır. Evleri Abhazların evleri gibi dağınık değildi. Onlar, yan yana ve duvarları örülmüş çalıdan oluşan hafif yarım kargir evler yapmışlardır. Çevredeki başka bir bölgenin, suyu, toprağı, otlakları ve ağaçlarıyla daha çok hoşlarına gitmesi durumunda köylerini terk etmişler ve kısa zamanda orada yeni bir köy kurmuşlardır (Güldenstädt 1834: 132-137).

10 Rurik Hanedanı'na mensup olan ve Korkunç İvan olarak da bilinen İvan Vasilyeviç (1547-1584), kendini Rusya çarı olarak ilan eden ilk Moskova büyük prensidir. İdari, hukuki ve askeri alanda esaslı reformlar yapmıştır. Devletin sınırlarını bilhassa Tatar bölgelerini ele geçirerek genişletmiş ve Kafkasya'ya kadar ilerlemiştir. Osmanlı Devleti, bütün gücünü Batı'da Avusturya'ya, Doğu'da ise İran'a karşı yoğunlaştırdığında, çar bunu firsat bilerek 1552'de Kazan'1, 1556 'da ise Astrahan'ı ele geçirmiştir. Bu arada Kabardin ve Çerkez liderleri, Çar İvan'dan Osmanlı'ya karşı himaye talep etmiştir. İlk önce buna olumlu yaklaşmayan Çar, daha sonra 1560 yılında karısı Anastasia'nın ölümünden sonra Çerkez Prensi Temrink'in (Temryuk) kızı Maria Temryukovna ile evlenmiş ve Çerkez bölgesindeki Rus nüfuzunu güçlendirmeyi başarmıştır (Kämpfer 1995: 27 49; Yildız 2014: 308). 


\section{Jacob Reineggs}

18. yüzyıl Çerkez kültürü hakkında gözlemlerde bulunan başka bir Batılı seyyah, 1780'li yıllarda Rus Çarlı̆̆ı'nın hizmetinde çalışan Alman Araştırmacı ve Doktor Jacob Reineggs'dir (Ölm. 1793). Özellikle Çerkezlerin toplumsal yaşamları üzerinde duran Reineggs'in notları kısa olmakla birlikte, Çerkez tarihinin aydınlatılması bakımından büyük önem taşımaktadırlar. Reineggs'in ağırlıklı olarak Çerkezlerin en büyük boyu olan Kabardinlerden bahsettiğini görüyoruz. Seyyahın tespitlerine göre Kabardinler, ölçülü bir hayat yaşayan bir topluluktu. Çok misafirperver olan Kabardinler, kendilerinin ve dostlarının işleri için olağanüstü gayret sarf ederlerdi. Onlar, at, koyun, sı ğır, bal, balmumu ve köle ticaretiyle uğraşırdı. Başlıca geçim kaynağı hayvancılık olan Kabardinler, sürülerinin ve damızlık hayvanlarının çokluğu nedeniyle, yaz aylarında daima taze ot bulmak için kamp yerlerini günlük değiştirmek zorunda kalırdı. Kış yaklaşınca, sap, arpa ve darı samanı bulunan köylerine geri dönerlerdi. Sağılan inekler, buzağıları yanlarında olmadan bir damla bile süt vermezdi. $\mathrm{Bu}$ nedenle buzağı, inek sağılana kadar onun ön ayaklarından birine bağlanırdı. Tarımla da uğraşan Kabardinler, darı ve mısır ve az da olsa buğday ekerlerdi. Kilerlerinde her zaman bal, bal likörü, kaliteli bira, süt ve peynir bulundururlardı. Onlar, at eti yemese de ekşitilmiş at sütünü çok severdi. Taze yaptıkları peyniri, geniş ve yuvarlak parçalar halinde keten kumaşlar içine koyup dumana tutarlardı. Böylece peynir, tadı hiç bozulmadan yazın sinek ve kurtlardan korunmuş olurdu.

Reineggs, Çerkez kadınlarının çok güzel olduğu konusundaki söylentiyi çok abartılı bulmaktadır. Ona göre, makyajsız olarak bile ateşli ve canlı bir gençliğe sahip olan Gürcü kızları ve zarif vücutlu, mavi gözlü İran kızları, yuvarlak ve sert vücutlu muzip Çerkez kızlarından daha güzeldi. Çerkezleri güzel kılan, onların kısa baldırlar, küçük ayaklar ve parlak kızıl saçlara sahip olmasıydı. Çerkez güzellerinin şen şakrak ve nazik tavırları da onları çok çekici kılıyordu. Ayrıca onlar, komik, şakacı, muzip, titiz ve çok konuşkandılar. Gençliklerinde açıkça göze çarpan gururlarıla erkeklere hükmediyorlardı. Fakat yaşlılıklarında, dayanılmaz şekilde huysuz ve hırçın oluyorlar ve halı örtülü bir karyolada bütün gün yat1yorlard1 (Reineggs 1796: 260-262). 


\section{Peter Simon Pallas}

Güldenstädt gibi Rus Bilim Akademisi'nde görevli olan ve II. Katharina adına araştırmalar yapmak için 1768-1794 yılları arasında Hazar Denizi bölgesine ve Kafkasya'ya birçok seyahat düzenleyen (Auch 1997: 89) Alman Doğa Araştırmacısı ve Coğrafyacı Peter Simon Pallas'ın (Ölm. 1811), 18. yüzyıl Çerkez toplumu hakkında, Güldenstädt ve Reineggs'e nazaran daha ayrıntılı bilgiler sunduğunu görüyoruz.

Pallas da Güldenstädt gibi, Çerkezlerin, özellikle Kabardinlerin köylerde oturduğunu, fakat zaman zaman bu köyleri terk ettiklerini belirtmektedir. Pallas'a göre, "Çerkezler, köylerinde ve evlerinde çok temiz yaşıyorlard ve onlartn elbiseleri ve yemekleri de temizdi."Ancak Pallas'a göre Çerkezlerin köylerini terk etmesinde, artan kirlilik, asayişsizlik ve diğer rahatsızlık verici bazı faktörlerin de önemli bir rolü olmuştur. Sözü edilen nedenlerden dolayı köylerini bırakan Çerkezler, genellikle kaliteli keresteler ve bazı önemli ev eşyalarını yanlarına alır ve geriye kalan eşyaları yakarlardı. Daha sonra köy kurmak için yeni bir yer bulunurdu. Bu arada, kurulan yeni köyün, bir su kaynağına yakın olmasına dikkat edilirdi. Su ihtiyacını karşılamak için, en yakın çayda, küçük barajlar kurulur ve su, bir kanal vasitasıyla köye yönlendirilirdi. Evlerin, dairesel ya da karesel alanlar içerisine yan yana inşa edilmesine özen gösterilirdi. Böylece evlerin çevrelediği avlu şeklindeki tek kapılı iç mekân, belli ölçüde de korunaklı olan ortak bir ağıl teşkil ederdi. Dikdörtgen planlı evler, 4-5 kulaç uzunluğunda ve bir buçuk kulaç genişliğinde yapılıyordu. Evlerin sepetlere benzeyen sık örgülü dış ve iç duvarları, yoğun olarak balçıkla sıvanıyordu. Örgü yapının üstü, merteklerden yapılmış ve uzun otlarla örtülmüş hafif bir çatıyla kapatılıyordu. Bütün ev, kadına ait olan büyük bir oda ve köleler ve kızlara ait olan küçük bir yan odadan oluşmaktaydı. Erkekler, özel bir dairede otururlardı. Her evde bir ocak, onun yanında, güzel halılar ve oymalı yastıklar ve döşemelerle donatılmış bir divan veya bir oturak bulunurdu. Oturağın arkasındaki duvarlara, çeşitli eşyalar ve elbiseler, çatının merteklerine ise başaklarıyla buğday ve mısır koçanları asilird1.

"Usden" adı verilen prenslerin çok odalı evleri ise, evlerin yapıldı̆̆ 1 daireler dışında müstakil olarak inşa edilmekteydi. Bazen köylerde, içlerinde bir ocak, küçük bir divan ve rahatllğa yönelik her türlü imkân bulunan, yaklaşık iki kulaç genişliğinde, kare planlı misafirhanelere de 
rastlanmaktaydı ve onlar da prens evleri gibi müstakil inşa ediliyordu. Ayrıca yuvarlak kulübeler şeklindeki örgü tuvaletler de evlerden müstakil yerlerde bulunuyordu. Köylerin etrafında sık sık, saman ve tahıl yığınları ile harmanlanan tahılın içine konulduğu toprağa bağlanmış kapaklı büyük sepetlere rastlanırdı. Köylerin en önemli parçalarından olan mezarlıklar ise köyün yakınına ve biraz yüksek olan yerlere kuruluyordu. Kare taşlardan yapılan dikdörtgen şeklindeki bazı gösterişli mezarların köşelerine ahşap başlı sütunlar ilave ediliyordu. Prensler ve diğer soylular için daha büyük ve yontma taşlardan oluşan, altı, yedi, sekiz köşeli duvarları olan mezarlar, hatta anıt mezarlar yapıliyordu. (Bkz. Resim 2)

Resim 2: Çerkez Soylularına Ait Anıt Mezarlar

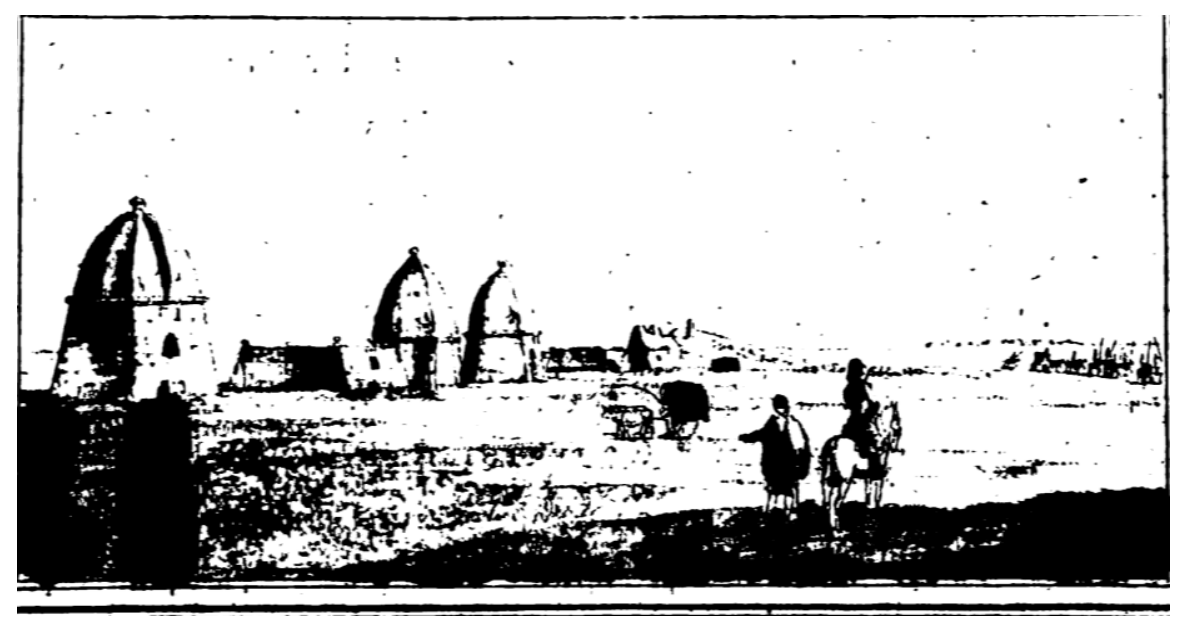

Kaynak: Pallas 1799: 319

Tarım ve hayvancılıkla uğraşan Çerkezler, ağırlıklı olarak darı ekmişlerdir. Darıdan hem lapa pişiriliyor hem de birçok hamur işi ve özellikle de pide türü bir ekmek yapılıyordu. Ayrıca darıdan Hantkups ${ }^{11}$ adı verilen bir içecek imal ediliyordu. Çerkezlerin en çok sevdiği içecek bal likörü olduğu için onların en önemli uğraşlarından biri de arıcılıktı. Çerkezler arıları, ağaçların alçak kısımlarına rahatça astıkları ve başka yerlere de rahatlıkla taşıyabildikleri sepetlerde beslemişlerdir. Üretilen balın en kalitelisini, kısmen likör yapımında kullanmışlar, kısmen darıdan elde edilen mayalanmış bozaya katmışlar, kısmen de satmışlardır. Çerkezlerin

11 Muhtemelen Çerkezce olan "hantkups" kelimesi birçok Batılı kaynakta geçmesine rağmen bu kaynaklarda kelimenin anlamı verilmemiştir. Yalnızca bir kaynakta, hantkupsun darıdan yapılan bir likör olduğu belirtilmektedir (Griffiths 1799: 488). 
beslediği başlıca hayvanlar, keçi, koyun, sığır ve attı. Bilhassa at yetiştiriciliğinin Çerkezlerde özel bir yeri vardı. Onlar, şövalyelikleri atın kalitesine bağlı olduğu için, atların sadece güzel olmasına değil, aynı zamanda güçlü, açlık ve zorluklara karşı dayanıklı ve hızlı olmasına büyük önem vermişlerdir.

Resim 3: Çerkez ve İnguş Arı Sepetleri

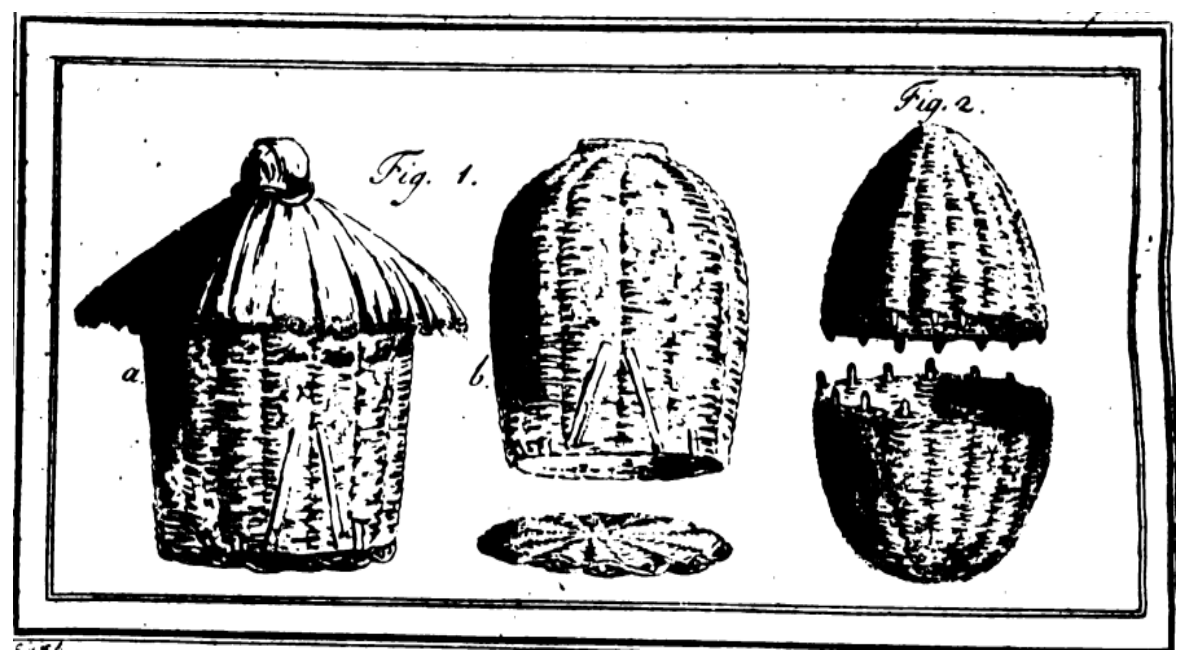

Kaynak: Pallas 1799: 424

Çerkezler genel olarak güzel bir ırktı. Erkekler, özellikle soylu olanlar, cüsseli, ince, Herkül yapılı, ince kalçalı, küçük ayaklıydı. Yumrukları ve kıliçları kuvvetli olan Çerkez erkekleri, âdeta Romalılara ve cengâverlere benziyorlard. Kadınların hepsi tipik Çerkez güzelliğine sahip değildi, ancak geneli güzel yapılı, beyaz ciltli, koyu kahverengi veya siyah saçlıydı ve muntazam yüz hatlarına sahipti. Süslenmek, Çerkezlerde müstehcen sayılsa da, kızların tırnaklarına kına yakmasına izin verilmiştir.

Her toplumda olduğu gibi, Çerkezlerde de aristokrat sınıf, toplumda büyük bir üstünlüğe ve belli ayrıcalıklara sahipti. Prensler tebaalarından birini, eğer hak ediyorsa soylu ilan edebiliyor ya da birinin elinden her şeyini alabiliyordu. Eli kılıç tutan herkes, özellikle soylular, prensle birlikte savaşa katılmak zorundaydı ve korkaklık en ağır şekilde aşağılanmak suretiyle cezalandırılıyordu. Pallas'a göre halk üzerinde önemli ölçüde tasarruf hakkı bulunan prens ve şövalyelerin, savaş, ganimet amaçlı saldırılar düzenlemek ve avdan başka bir meşguliyetleri yoktu. Hatta onlar bazen içki âlemleri de yapıyorlard. Her çiftçi bir soyluya ya da prense üç gün saman yapıp odun keserek evine getirmek zorundaydı. Ayrica o, 
soylunun her öküzü için bir araba dolusu ya da 7 çuval darı vermek zorundaydı. Prens çocukları doğar doğmaz, eğitim için soylu bir aileye verilirdi ve anne baba, özellikle baba, oğlunu bir yetişkin olup silah kullanıncaya kadar görmezdi. Anne babalar, kız çocuklarını da evlenene kadar görmezdi. Erkekler, Çerkezlerde erdem sayılan şövalyelik ve ganimet toplama gibi alanlarda eğitilirken, kızlara da dikiş, nakış, örgü, elbise dikme, hasır dokuma, sepet örme gibi kadın işleri öğretilirdi. Eğitici kellesini kaybetmek istemiyorsa, kızın içtimai mevkiine uygun bir damat bulup onu evlendirmek görevini de üstlenmek zorundaydı. Din adamları, halka nispetle çok daha ayrıcalıklı konumdaydılar. Din adamları ve din bilginleri, sakallarını tamamen uzatırlardı. Din adamları, genellikle kan kırmızısı bir sarık takar ve uzun kırmızı bir elbise giyerlerdi. Çerkezler, dindar Müslümanlar olmamalarına rağmen, din adamlarının onlar nezdinde büyük itibarı vardı.

Resim 4: Bir Çerkez Köylü ve Prens

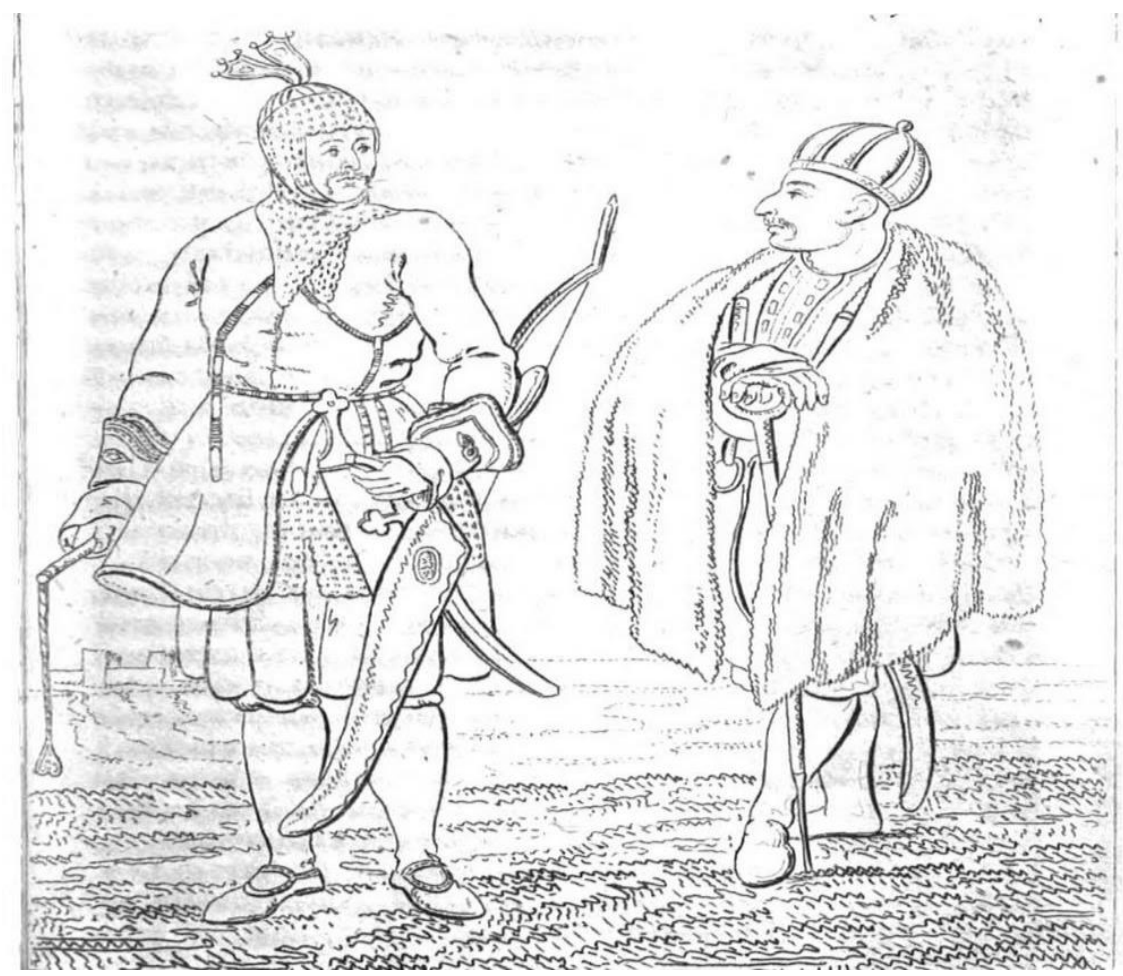

Kaynak: Mavor 1813: 133 
İlginçtir ki, birbirine zıt iki âdet olan kan davaları ve misafirperverlik Çerkez toplumunda özenle korunmuş ve yaşatılmıştır. Misafirlere özel bir önem veren Çerkezler, bir "konuk hukuku" geliştirmişler ve bu hukuk çerçevesinde bazı kurallar koymuşlardır. Konuk hukukundan yararlanan herkes, öncelikle bütün hakaretlere ve kötü muamelelere karşı koruma altına alınmıştır. Misafirperver olan kişi, gerektiğinde konuğunu kendisinin ve yakınlarının canı ve kanı pahasına korur ve onu, yanına şövalye koruması vermeden göndermezdi. Öldürülen bir konuğun intikamı, sanki bir akraba öldürülmüş gibi alınırdı. İlginçtir ki, bir kadının himayesine sığınan bir yabancı, düşman bile olsa, bir akraba gibi kurtarıliyor ve korunuyordu. İntikam almayan kişi, toplumdan dışlanmıştır. Öldürülen birinin ailesine kan davasından vazgeçmesi karşılı̆̆ında "Tilil Uasa" denilen bir ücret ödenebiliyordu. Fakat soylular, genellikle bu parayı almayıp kana kan prensibini sürdürmüşlerdir. Öldürülen birinin öcünü en yakın akrabası almak zorundaydı. Hatta kan davaları nesilden nesile intikal edebiliyordu (Pallas 1799: 378-394).

\section{Johann Gottlieb Georgi}

18. yüzyıl Çerkezleri hakkında bilgi veren Batılı seyyahlardan biri de yine aynı şekilde Rusya Bilimler Akademisi'nde görevli olan Alman Bitkibilimci ve Coğrafyacı Johann Gottlieb Georgi'dir (Ölm. 1802). Fakat Georgi'nin sunduğu bilgiler hem çok kısa hem de çok geneldir. Georgi'nin Çerkezler hakkında verdiği bilgileri şöyle özetleyebiliriz: Çerkezler, Türkler ve Gürcüler tarafindan "Çerkeslani”, Avrupalılar ve Ruslar tarafındansa "Çirkassen" olarak adlandırılmıştır. Rus Çarı İvan, 16. yüzyılda Çerkezleri hâkimiyeti altına almış ve onlar arasında Hristiyanlığın yayılmasında belli bir başarı sağlamıştır. Çerkezler, 17. yüzyılda Kırım Hanlı̆̆ı'nın hâkimiyeti altına girmişler ve onlara bağlılıklarının bir göstergesi olarak, hanların haremi için yıllık bir kız, bir at ya da bir panzer vergi ödemişlerdir. Bazen de Kırımlı komiserler Çerkezistan'a gelmiş ve haraç olarak verilecek şeyleri kendileri seçmişlerdir. Bu nedenle Çerkezler, 1708 yılında komiserleri öldürmüşler ve Kırım birliklerini yenmişlerdir (Georgi 1776: 132-133).

\section{Sonuç}

Jean-Baptiste Tavernier, 17. yüzy1l, Johann Anton Güldenstädt, Jacob Reineggs, Peter Simon Pallas ve Johann Gottlieb Georgi ise 18. yüzyıl Çerkez kültürü ve toplumsal yaşamı hakkında bize çok değerli bilgiler 
sunan Batılı seyyah ve araştırmacılardır. Sözü geçen yüzyıllarda, Çerkezleri, mümkün olduğu kadar bütün yönleriyle gözlemlemeye çalışan bu seyyahlar, edindikleri bilgileri özenle not etmişler, hatta bazen görsel tasvirlere de yer vermişlerdir ki, biz bunlardan bazılarını metin içerisinde çalışmamıza eklemiş bulunuyoruz.

Her şeyden önce bu seyyah ve araştırmacıların, tasvirlerinde, kendi açılarından ilginç gözüken noktalar üzerinde durduklarını belirtmek gerekmektedir. Bu nedenle ister istemez onlar, Çerkez kültürü ve sosyal yaşamının belli noktalarını ayrıntılı olarak ele alırken, bazı noktalarına kısaca değinmekle yetinmişlerdir. Örneğin, giyim kuşam kültürü çerçevesinde kadın ve erkeklerin kıyafetlerinin hemen hemen aynı tarzda olduğu vurgulanmış ve Çerkezlerin kendilerine özgü elbiseleri ayrıntılı olarak tasvir edilmiştir. Seyyahlar, Çerkez köyleri ve bu köyleri oluşturan evlerin mimarisi ve iç donanımları hakkında da birçok değerli bilgiler sunmuşlardır. Çerkez köyleri bağlamında özellikle iki husus dikkatimizi çekmektedir. Birincisi bu evlerin, çalı ve buna benzer malzemenin ustalıkla örülmesiyle yapılması, ikincisi ise Çerkezlerin, köylerinde rahatsızlık verici bazı olumsuz şartların ortaya çıkması durumunda köyü terk ederek kısa zamanda yeni bir köy kurabilmesidir. Batılı seyyahların ayrıntılı tasvir ettiği alanlardan birinin de, Çerkezlerin tören ve bayramları ve bu vesileyle verdikleri ziyafetler olduğunu gördük. Baş menüsü koyun ya da keçi olan ve bütün köy halkının genç, yaşlı, çocuk, kadın, erkek, tamamının istisnasız katıldığ 1 bu ziyafetlerin belli kurallar ve ritüeller çerçevesinde icra edilişi özellikle dikkatimizi çekmiştir. Bu şenlikler aynı zamanda eğlence kültürünün Çerkez toplumsal yaşamının vazgeçilmez unsurlarından biri olduğunu göstermektedir.

Seyyahlar, Çerkezlerin başlıca gelir kaynağını, tarım, köle ticareti ve hayvancılık olarak göstermektedirler. Bu bağlamda Çerkezler, iyi bir şövalye olabilmek için her şeyden önce kaliteli bir ata sahip olmak gerektiği için, at yetiştiriciliğine özel bir önem vermişlerdir. Seyyahlar, Çerkezlerin yemek ve içecek kültürü konusunda da bazı ilginç bilgiler sunmuşlardır. Örneğin Çerkezler, ağırlıklı olarak buğday değil darı yetiştirmişler ve ekmeği darıdan yapmışlardır. Hatta onlar darıdan, yemek ve diğer hamur işleri dışında çok severek içtikleri boza ve hantkups (darı likörü) adında iki içecek de imal etmişlerdir. Ayrıca seyyahlar eserlerinde, kan davası, misafirperverlik, hasta tedavi yöntemleri, ölü defnetme âdetleri, mezar mimarisi, sık kullanılan bazı isimler, soyluların yaşamı, evlenme ve düğünler, Çerkez güzelliği, sövalyelik, avcılık gibi Çerkez 
kültürü ve sosyal yaşamına dair birçok konuda değerli bilgiler sunmaktadırlar. Hatta onlar, Çerkezlerin kısmen diğer komşu halklar, Rus Çarlığı, Kırım Hanlığı ve Osmanlı İmparatorluğu ile ilişkileri konusunda da bazı bilgiler vermektedirler.

Seyyahların verdiği bilgiler, genel olarak birbiriyle örtüşse de bazı bilgiler abartılı gözükmektedir. $\mathrm{Bu}$ da onların, her zaman kendi gözlemlerinin sonuçlarını değil, bazen de duyduklarını nakletmiş olabilecekleri ihtimalini akla getirmektedir. Örneğin seyyahların, Çerkezlerin beslediği hayvanlar, tarım ve yeme içme kültürleri, evlerinin mimarisi gibi konulardaki ifadeleri hemen hemen birbirinin aynısıdır. Ancak Tavernier'in ve Pallas'ın, soyluların ve şövalyelerin bütün meşguliyetlerinin savaş ve ganimet seferleri yapmak olduğu ve geçimlerini bundan sağladığı konusundaki ifadeleri abartılıdır. Onların bütün gelir kaynaklarını ve meşguliyetlerini burada sayamayız, ama örneğin prenslerin vergiler başta olmak üzere birçok gelir kaynağı olduğu bilinen bir gerçektir. Sonuç olarak Batılı seyyahların Çerkez toplumu hakkında yaptıkları gözlemler ve araştırmalar sonucunda seyahatnamelerine yansıttıkları bilgiler çok değerli olup Çerkezlerin hem siyasi hem de kültürel tarihinin aydınlatılmasına önemli katkı sağlamaktadır.

\section{Kaynaklar}

Aretz, Gertrude (2012), Kaiserin Katharina II. Biographie, Hamburg: Severus Verlag.

Auch, Eva-Maria (1997). "Zum Muslimbild deutscher Kaukasusreisender im 19. Jahrhundert". "Barbaren" und "Weise Teufel". Kulturkonflikte undImperialismus in Asien vom 18. Jahrhundert bis zum 20. Jahrhundert. hrsg. von Eva-Maria Auch und Stig Förster, Paderborn, München, Wien, Zürich: Schöningh. s. 83-100.

Berkok, İsmail (1958). Tarihte Kafkasya, İstanbul: İstanbul Matbaası.

Bilge, Sadık Müfit (2012). Osmanlı Çağı'nda Kafkasya 1454-1829 (TarihToplum-Ekonomi). İstanbul: Kitabevi.

Fauser, Alois (1966). "Güldenstädt, Johann Antonn”, Neue Deutsche Biographie, Bd. 7, Berlin: Duncker \& Humblot.

Gärtner, Rainer W. (2001). "Pallas, Peter Simon”, Neue Deutsche Biographie, Bd. 20, Berlin Duncker \& Humblot, s. 14-16. 
Georgi, Johann Gottlieb (1776). Beschreibung aller Nationen des Russischen Reiches, ihrer Lebensart, Religion, Gebräuche, Wohnungen, Kleidungen und übrigen Merkwürdigkeiten, zweite Ausgabe. St. Petersburg: Bei Karl Wilhelm Müller, s. 254-255.

Griffiths, Ralph and Griffiths, George Edward (eds.), Monthly review or literary journal enlarged: From september to december, vol 30 (1799), s. 488.

Güldenstädt, Johann Anton (1834). Dr. J. A. Güldenstädt's Beschreibung der Kaukasischen Länder. aus seinen Papieren gänzlich umgearbeitet, verbessert herausgegeben und mit erklärenden Anmerkungen begleitet von Julius Klaproth, Berlin: Im Verlage der Stuhrschen Buchhandlung.

Hoppe, Hans-Joachim (2011), "Die Tscherkessen - ein unbekanntes Volk erwacht", (https://www.eurasischesmagazin.de/artikel/DieTscherkessen-ein-unbekanntesVolkerwacht/20111009, 3 Nisan 2018'de erişildi).

Kämpfer, Frank (1995). "Ivan (IV.) der Schreckliche 1533-1584”, Torke, H. J. (Ed.), Die russischen Zaren: 1547-1917, München: Beck Verlag, 27-49.

Komkov, G. D., Levşin, B. V., Semenov, L. K. ve Grau K. (1981). Geschichte der Akademie der Wissenschaften der UdSSR, Berlin: Akademie-Verlag.

Mavor, William Fordyce (1813). A general collection of voyages and travels, including the most interesting records of navigators and travellers, from the discovery of America by Columbus, in 1492, to the travels of Lord Valentia. London: Printed for Sherwood, Neely \& Jones.

Natho, Kadir I. (2009). Circassian History, New York: Xlibris Corporation.

Pallas, Peter Simon (1799). Bemerkungen auf einer Reise in die südlichen Statthalterschaften des Russischen Reiches in den Jahren 1793 und 1794. Bd. 1. Leipzig: Gottfried Martini.

Reineggs, Jacob (1796). Allgemeine historisch-topographische Beschreibung des Kaukasus, aus seinen nachgelassenen Papieren gesammelt und herausgegeben von Friedrich Enoch Schröder, Bd. 1, Gotha und St. Petersburg: Gerstenberg und Dittmar. 
Sarkisyanz, Emanuel (1961). Geschichte der orientalischen Völker Rußlands bis 1917. München: Oldenbourg.

Schipperges, Heinrich (1967), "Jacob Reineggs (1744-1794): Arzt, Orientalist und Abenteurer", Hoenerbach, Wilhelm (Ed.): Der Orient in der Forschung: Festschrift für Otto Spies zum 5. April 1966, Wiesbaden: Harrassowitz, s. 586-597.

Tavernier, Jean-Baptiste (1681). Beschreibung der sechs Reisen, welche Johan Baptista Tavernier, Ritter und Freyherr von Aubonne, in Türckey, Persien und Indien innerhalb viertzig Jahren, durch alle Wege, die man nach diesen Länderen nehmen kan, verrichtet: Worinnen unterschiedliche Anmerckungen von der Beschaffenheit der Religion, Regierung, Gebräuchen und Handlungen jeglichen Landes enthalten. Samt den Figuren, Gewichten und dem Maß der Müntzen, welche in diesen Ländern gangbar sind. Anfangs Frantzösisch beschrieben und in drey Theil abgetheilt, anjetzo aber nebenst der Beschreibung des Türckischen Serrails, und der Krönung des jetzt Regierenden Königs in Persien, in der HochTeutschen Sprach ans Liecht gestellt, durch Johann Herman Widerhold, Erster Teil, Genff: Widerhold.

Wendland, Folkwart (1992). Peter Simon Pallas (1741-1811): Materialien einer Biographie, Berlin: Walter de Gruyter. 